\title{
Hvad kan HyFlex-organiseret undervisning?
}

\section{- De studerendes tilgang}

Helle Mathiasen, Københavns Universitet

Henrik Bregnhøj, Københavns Universitet

\section{Abstract}

Fokus i artiklen er på kommunikationens betingelser i HyFlex-undervisning, hvor halvdelen af de studerende på skift kan møde op på campus, mens resten kan følge undervisningen live online. En e-moderator i forelæsningslokalet fungerer som et kommunikativt bindeled mellem onlinedeltagerne og forelæser.

Artiklens empiri omfatter en kvantitativ og kvalitativ del og har fokus på forelæsninger og de studerendes kommunikative deltagelse.

Undersøgelsesresultaterne fortæller bl.a., at 74\% af studerende vælger at følge forelæsningerne online, og at de studerende er enige om, at HyFlex er en god og fleksibel forelæsningsorganisering. Argumenterne for valg af onsite/online-deltagelse viser en vifte af individuelle præferencer.

E-moderator-funktionen er vigtig. Onlinestuderende er mere kommunikativt aktive mht. faglige spørgsmål (gennemsnitlig et bidrag fra hver tredje onlinestuderende i chatten). Chatkommunikationen initierer spørgsmål/svar via e-moderator (IRE-triader), mens interaktion forelæser/onsite og onsite/onlinestuderende (interaktionskæder) har vanskelige vilkår. De studerendes oplevelser indbefatter sparring, spejling, afveksling, engagement og motivation som vigtige parametre for deres tilgang til HyFlex-undervisning.

\section{Engelsk abstract}

The article focuses on the conditions of communication in HyFlex teaching, where half of the students can be on campus every second time, while the rest can follow the teaching live online. An e-moderator in the lecture room acts as a communicative link between the online participants and the lecturer.

The empirical data includes a quantitative and qualitative part and focuses on lectures and the students' communicative participation.

The survey results show, among other things, that $74 \%$ of students choose to follow the lectures online and that the students agree that HyFlex is a good and flexible lecture organization. The arguments for choosing onsite / online participation show a range of individual preferences.

The e-moderator function is important. Online students are more communicatively active in academic matters (on average one contribution from every third online student in the chat). Chat communication initiates questions / answers via e-moderator (IRE triads), while interaction lecturer / onsite and onsite / online students (interaction chains) have difficult terms. The students' experiences include sparring, reflection, variety, commitment and motivation as important parameters for their approach to HyFlex teaching. 


\section{Indledning}

Universiteterne har været udfordret siden foråret 2020. Både studerende, undervisere og ledelse har oplevet personlige, sociale og faglige udfordringer. Undersøgelser om den såkaldte nødundervisning forårsaget af Corona-pandemien er blevet gennemført i stor stil i 2020 på uddannelsesinstitutionerne (fx Jensen et al, 2020) og på tværs af institutioner (Georgsen \& Qvortrup (red.), 2021, Mathiasen et al, 2020). Også uden for landets grænser er der indsamlet erfaringer (eksempelvis www.postpandemicuniversity.net).

Rapporter og artikler fortæller om underviseres og studerendes erfaringer med net-medieret undervisning og om den flerhed af udfordringer, der er oplevet af både teknisk, faglig, personlig og social art (https://uniavisen.dk/to-forelaeseres-gyserdagbog-fra-en-maaned-med-digital-undervisning/).

Corona-relaterede restriktioner har betydet, at campusbaseret onsite undervisning har skullet finde nye organiseringsformer. Denne artikel fokuserer på forelæsninger, der omfavner både on-campus (onsite) og net-medieret undervisning (online) samtidig, hvilket var muligt i efteråret 2020 indtil begyndelsen af december, hvor nye Corona-restriktioner betød, at forelæsninger udelukkende kunne gennemføres i et rent onlineformat.

Formålet med artiklen er, med udgangspunkt i casestudiet, at bidrage til diskussionen om, hvad HyFlexorganiserede forelæsninger kan og ikke kan.

HyFlex-undervisningsmiljøer byder på en særlig kompleksitet, idet forelæser skal tænke sig selv som deltager i to undervisningsmiljøer på samme tid. Forelæser skal således kommunikere med onsitedeltagende studerende og samtidig tænke i kommunikation med online deltagende studerende. Udfra et kommunikationsteoretisk perspektiv er konditionerne for kommunikation i de to miljøer væsensforskellige, hvilket de studerende ligeledes kan opleve, når de veksler mellem at deltage $\mathrm{i}$ forelæsningerne onsite og online. Artiklen har som teoretisk fokus kommunikation, hvilket vil blive udfoldet i sammenhæng med begreberne undervisning og læring. Den teoretiske ramme inkluderer endvidere didaktiske aspekter i forhold til HyFlex-undervisning.

Det overordnede forskningstema handler om kommunikationens mulighedsbetingelser (Luhmann 1992) i en sådan undervisningsorganisering. Vi spørger i den kvalitative del af undersøgelsen om, hvordan betingelserne for kommunikation i HyFlex-undervisningsorganisering opleves af de studerende, og hvilke tilgange og præferencer de i den sammenhæng giver udtryk for. I den kvantitative del spørger vi til volumen af de studerendes kommunikative deltagelse i HyFlex-organiseret undervisning med tilknyttet e-moderator.

Den konkrete undervisningsorganisering, der er casestudiets omdrejningspunkt, betegnes HyFlex (Hybrid \& Flexible), hvor der på samme tid skal undervises onsite og online. Artiklen vil indledningsvis udfolde begrebet HyFlex-organiseret undervisning og efterfølgende beskrive rammer og den konkrete undervisningskontekst for casestudiet.

Derefter følger en beskrivelse af det empiriske design. Med udgangspunkt i de indsamlede data fra henholdsvis den kvantitative og den kvalitative undersøgelse præsenteres og diskuteres analyseresultater, og artiklen afsluttes med konkluderende pointer med udgangspunkt i den anlagte kommunionsteoretiske ramme.

\section{Hvad er HyFlex-undervisning?}

HyFlex er en sammentrækning af Hybrid og Flexible. Hybrid fordi studerende undervises både i auditoret (onsite) og online på samme tid (livestreamet med kamera og mikrofoner i auditoriet), og 
flexible fordi hver enkelt studerende selv kan vælge, hvordan de følger den enkelte undervisningsgang. Denne undervisningsform blev udviklet på San Francisco State University omkring 2007 og i 2016 kondenserede universitetet definitionen til: "HyFlex courses are class sessions that allow students to choose whether to attend classes face-to-face or online, synchronously or asynchronously." (Beatty, 2019). Undervisningen optages og gøres tilgængelig efter undervisningssessionen sammen med anvendt materiale. Intentionen er, at studerende får samme muligheder for at lære det, der fordres i såvel synkrone som asynkrone undervisningsmiljøer (Beatty, 2019).

HyFlex-organiseret undervisning kræver et teknisk setup med som minimum kamera og mikrofon på forelæser (evt. også til onsitestuderende), computer med live streaming software og derudover enten højttalere eller en e-moderator, som kan mediere kontakten til onlinestuderende, samt evt. en videoplatform til optagelserne.

\section{HyFlex-undervisning, rammer og kontekst for casestudiet}

Det Sundhedsvidenskabelige Fakultet på Københavns Universitet (KU SUND) tilbød mulighed for HyFlex-undervisning for alle studieretninger efter sommerferien 2020. Undervisere kunne deltage i webinarer for at lære at bruge HyFlex, og der blev over sommeren opgraderet med flere faste kamera/lydløsninger i auditorier samt udlånsudstyr.

Herudover kunne kursusledere og forelæsere anmode om hjælp fra en e-moderator til de enkelte forelæsninger. E-moderatorkorpset bestod af en gruppe på 11 studerende ( $\max 15$ timer/uge), som selv håndterede undervisernes anmodninger og samarbejdede især ved at dele de erfaringer, de opnåede. Hele setuppet blev koordineret af KU SUNDs Center for Online and Blended Learning (COBL), der i efteråret 2019 havde haft et semesters erfaring med at udvikle livestreaming.

E-moderatorer havde flere funktioner. En teknisk funktion inkluderende sikring af at det nødvendige udstyr (software, mikrofon $\mathrm{mm}$ ) virkede og aftaler med forelæser før forelæsningen. E-moderator styrede også kamera, så onlinestuderende både kunne se forelæsers gestik, mimik, bevægelse rundt i auditoriet, tavleaktiviteter og storskærmspræsentationer $\mathrm{fx}$ i form af slideshow og video. E-moderator faciliterede grupperum for onlinestuderende og styrede særlig software for underviser.

Herudover havde e-moderator en kommunikativ dobbeltfunktion; e-moderator skulle følge med i chatten, og når en onlinestuderende skrev et spørgsmål til forelæser, skulle e-moderator markere til forelæser, og derefter præsentere spørgsmålet i auditoriet. Endvidere skulle e-moderator være i dialog med onlinestuderende, hvis der skulle opstå problemer med fx lyd eller muligheden for at se forelæsers tavleaktiviteter. Efter forelæsningen indrapporterede e-moderator data om sessionen, uploadede optagelsen og gjorde den tilgængelig for de studerende, hvis forelæser ønskede det.

Casestudiet omfattede observationer af tre kurser: Basal farmakologi (farmacistudiet), Medicinsk psykologi og sundhedspsykologi (medicinstudiet) og Cytologi og almen histologi (veterinærstudiet). Alle forelæsninger foregik i auditorier. Den tekniske opsætning var et kamera på stativ, trådløs knaphulsmikrofon på underviseren og ingen mikrofon til onsitestuderende. Zoom blev brugt til at dele video og lyd. Zoom chatten blev brugt til kommunikation, med og mellem onlinestuderende. Halvdelen af de studerende havde fået lov til at møde frem i auditoriet. 


\section{Teoretisk ramme}

Rammesætningen er HyFlex-organiseret undervisning med 100+ studerende. Det giver nogle konkrete didaktiske og kommunikative udfordringer. Det såkaldte triade-mønster, I-R-E, der står for henholdsvis 'Initiation', 'Response' og 'Evaluation' (Lemke, 1990; Mehan, 1979) er udfordret kommunikationsmæssigt, når onlinestuderende 'Responderer' (i chatten) på forelæsers spørgsmål ('Initiation'), og forelæser må afslutte med 'Evaluation' uden i praksis at kunne stille et hurtigt opfølgende 'Response', - eller når onsitestuderende ikke 'markerer en Response', og forelæser 'alene' må foretage 'Evaluation'. HyFlex-organiseringen byder på kommunikative og didaktiske udfordringer på flere niveauer. 'Evaluation'/opfølgning på studerendes svar kan have forskellige funktioner, som fx om svaret er rigtig eller forkert, en udfoldning af mulighederne for svarrummet og inddragelse af andre perspektiver i svaret/svarene. Kompleksiteten øges, når undervisningsmiljøet både indeholder en onsite og en online kontekst. De forskellige rammesætninger for kommunikationens opretholdelse har forskellige betingelser. En skriftlig interaktion har $\mathrm{fx}$ en anden beskaffenhed end en mundtlig interaktion, hvor den kommunikative båndbredde er større. Her er der mulighed for at flere deltagere synkront benytter kommunikative virkemidler som øjenkontakt og gestik. I det følgende præsenteres et kommunikationsbegreb inspireret af den tyske sociolog N. Luhmann (Luhmann, 1995). Dette begreb skal tjene som udgangspunkt for det analytiske fokus på kommunikationens mulighedsbetingelser i HyFlex-organiserede forelæsninger.

\section{Kommunikation og undervisning}

Det anvendte kommunikationsperspektiv er inspireret af Luhmanns kommunikationsbegreb (Luhmann, 1992) og valgt på grund af dets udsagnskraft, når kommunikationens mulighedsbetingelser i campusbaserede og netmedierede undervisningsformer er i fokus (Mathiasen, 2008).

En kommunikationsenhed er en syntese af tre selektioner (Luhmann, 1995), hvor de to første selektioner, henholdsvis valg af information og meddelelsesform, foretages af "den meddelende" (fx forelæser), mens den tredje selektion, valg af forståelse (af det af forelæseren meddelte), foretages af "adressat" ( $f x$ en studerende). En simpel form for kommunikation er en fortsat følge af forelæsers meddelte informationer, og den studerendes bestræbelser på at forstå den. Hvis forelæser vælger denne form for kommunikation, benævnes den som en monolog, og det kræver yderligere, at der mindst er en studerende, der 'vil' kommunikationen, og derfor retter sin opmærksomhed mod forelæsers meddelte informationer, for at der kan være tale om en syntese, én kommunikationsenhed. En monolog kan lidt firkantet karakteriseres som summen af kommunikationsenheder, hvor meddeler er den samme.

En monolog kan i sin kommunikative simpleste form karakteriseres som formidling, når det handler om ren envejskommunikation. Det kan fx være, at forelæser holder en onsite eller online forelæsning, og dermed fortløbende er den meddelende, og hvor den studerende ikke er tænkt som aktiv i forhold til at ytre sig med kommunikative bidrag.

En afgørende pointe med hensyn til det præsenterede kommunikationsbegreb er, at det kun er de første to selektioner, der kan observeres, mens den tredje selektion, valg af forståelse af det meddelte, ikke kan observeres. Når der i det empiriske design observeres, er det derfor kun de to første selektioner, der observeres. Adressat er en black box, og kun ved at fx forelæser (meddeler) spørger den studerende (adressat) til dennes forståelse af den meddelte information, og kun ved at den studerende, nu skiftet til meddelerrollen, får mulighed for at meddele sin forståelse til forelæser, som så er skiftet fra meddeler til adressat, kan forelæser konstruere sin forståelse af den studerendes meddelte forståelse. Og kun ved at forelæser efterfølgende spørger, nu som meddeler, den studerende om forelæsers konstruerede forståelse er korrekt i forhold til den studerendes forståelse, er betingelserne til stede for at forelæser og den studerendes konstruktioner af forståelsen afprøves. Med andre ord fortløbende 
kommunikationsenheder i en kæde, hvor meddeler og adressat løbende skifter roller, kan fremme en gensidig kommunikativ forståelse. Denne form for kommunikation benævnes interaktion. I litteraturen er interaktion bl.a. karakteriseret som forskellige former for 'chain patterns' (Scott et al, 2006). Skulle den beskrevne interaktion mellem en forelæser og en studerende beskrives som et kæde-mønster, kunne det fremstå som en lukket I-R-P-R-P-R-E, hvor triaden I-R-E er udvidet med 'Prompt', P, eksempelvis forelæsers opfordring til at den studerende udfolder sit svar eller pointe for til sidst at afslutte med 'Evaluation' (Scott et al, 2006, s. 612).

Hvis forelæser inddrager flere studerende (R1, R2, R3, R4, R5) i interaktionen kunne denne fx udvikle sig til følgende kæde-mønster, I-R1-P-R1-P-R2-R1-P-R2-R3-R1-P-R5-R2-E. Denne kæde illustrerer endvidere, at forelæser ikke 'prompter' efter hver ytring fra en studerende, men lader de studerende interagere med hinanden. Hvis en kæde ikke afsluttes med forelæsers validering, men i stedet står åben uden en afsluttende 'Evaluation', kan denne fx være en invitation til de studerende om yderligere fordybelse og søgen efter viden. I det tilfælde benævnes en kæde som åben (ibid).

En konsekvens af det valgte kommunikationsbegreb er, at den enkelte studerendes valg af forståelse først kan blive tolket af forelæser og af medstuderende, når alle har mulighed for kommunikativt at afprøve deres forståelser. Det kræver, at der er mulighed for interaktion, onsite og online. Forelæser og medstuderende kan ikke vide, om den enkelte studerende har valgt den forståelse, som forelæser intenderede med sine valg af fortløbende informationer og meddelelsesformer og brug af diverse teknologier. Disse teknologier kan have indflydelse på sandsynligheden for, at de studerende forstår den meddelte information som intenderet af forelæser. Det er dog en anden sag, om de intenderede læringsmål ækvivalerer med den studerendes, da det altid vil være den enkelte studerendes egen forståelse, der aktualiseres (Mathiasen, 2008). Den studerende vælger forståelse ud fra eget 'mentale beredskab' og egen iagttagelsesoptik. I den anlagte teoretiske ramme er resultatet af læring fortløbende videnkonstruktion og bygger på et konstruktivistisk læringsbegreb (Luhmann 1988). Onsite/onlinestuderende (og forelæser) indgår som deltagere i undervisningskommunikationen, når de retter deres opmærksomhed mod denne og kan dermed lære sig noget. Kommunikation konstituerer et socialt system, hvor bl.a. sociale relationer kan udvikles (Wubbles \& Breckelmans, 2005; Mathiasen, 2019b).

Forelæsninger er en blandt mange former for undervisning (Mathiasen, 2021). Selve begrebet undervisning forstås som den særlige form for kommunikation, der intenderer forandringer blandt de studerende, der retter deres opmærksomhed mod denne kommunikation. Et kommunikativt bidrag forstås som et kompleks af fx ord, gestik, mimik, fysisk bevægelse, intonation, pausering, taktile elementer, lugte og øjenkontakt, der kan understøtte forståelsen af det kommunikative bidrag. Den 'kommunikative båndbredde' afhænger af mængden af virkemidler, der er i spil.

En monologisk 'talking head'-videoforelæsning kan benytte sig af kommunikative virkemidler, som intonation, gestik og pausering og fx understøttes af slideshow med lyd og animationer. Et sådant format karakteriseres her som 'faglig formidling', da kommunikationen karakteriseres som monolog (Mathiasen, 2019a).

Tilstedeværelsesbaserede forelæsninger på campus kan ligeledes være monologisk, (envejskommunikation) og dermed også betegnes som faglig formidling. Hvis forelæsningen optages og gøres tilgængelig for de studerende karakteriseres dette format som en læringsressource og som faglig formidling.

Begrebet undervisning rækker kommunikativt ud over formidlingsformatet ved som udgangspunkt at have interaktion som en mulighed i den konkrete kontekst. Eksempelvis vil onsite-undervisning med oplæg, forskellige undervisningsaktiviteter og gruppe-/plenumdiskussioner være en kontekst, hvor den 'kommunikative båndbredde' kan aktualisere flere kommunikative virkemidler, og hvor den større kommunikative båndbredde giver den enkelte studerende og forelæser mulighed for at koble sig til undervisningen ved brug af de tilbudte kommunikative muligheder. 
I HyFlex-organiserede forelæsninger, hvor online-deltagende studerende kan stille spørgsmål i chatten til forelæser via e-moderatoren og efterfølgende få svar fra forelæser, og fra medstuderende i chatten samt deltage i chat-kommunikationskæder med medstuderende, er der tale om undervisning og ikke udelukkende om faglig formidling.

Kommunikation og dennes mulighedsbetingelser har betydning for læring og omvendt. Valg af undervisningsformer og organisering af undervisningen er afgørende som rammesætning for den intenderede kommunikation, det faglige tema for undervisningen og de intenderede læringsmål (Mathiasen, 2008).

\section{Empirisk design}

Artiklens casestudie benytter sig af et mixed method design (Hammersley \& Atkinson, 1987; Mathiasen, 2006, Creswell \& Clark, 2017). Undersøgelsen inkluderer således en kvantitativ og en kvalitativ del. Analysemetoden er inspireret af en meningskondenseringstilgang og tematisk analysetilgang (Kvale, 1997, Braun \& Clarke, 2006), og casestudiets gyldighed og validitet er muligt at efterprøve med det fremlagte empriske design. Casestudiet ses som netop en case, hvor vi opnår ny viden gennem et specifikt casestudie (Flyvbjerg, 2010). Den kvantitative del rummer dataindsamling under 282 forelæsninger i 38 kurser med gennemsnitligt 109 deltagende studerende. Fokus er på volumen af de studerendes kommunikative deltagelse i chatten under forelæsningerne. Yderligere er der indsamlet data vedrørende brug af kommunikationsredskaber/fora som quizzer, padlets, chats og breakout rooms.

Den kvalitative del består af online-observationer af HyFlex-undervisningen og sideløbende online lurking i det benyttede chatfora under forelæsningen. Observationerne blev efterfulgt af gruppeinterviews med studerende, der har deltaget i den observerede forelæsning. Disse 'observiews' giver muligheden for, at interviewer og informanter har en fælles referenceramme for interviewene af den observerede forelæsning (Kragelund et al 2015). Yderligere blev e-moderatorer bedt om skriftligt at svare på spørgsmål pr mail samt svare på opfølgende spørgsmål. Opmærksomhedspunkterne var omfanget af forelæsermonolog, interaktion mellem forelæser og studerende henholdsvis onsite- og online-deltagende samt kommunikation mellem de studerende i de to forskellige undervisningsmiljøer.

Forelæsningerne blev udvalgt på baggrund af informationer fra den kvantitative undersøgelse, og ud fra kriterier om at genstandsfeltet var forelæsninger, og at flere "store" uddannelser var repræsenteret.

De tre valgte forelæsninger (varighed: 2-3 lektioner) er alle på bachelor-niveau fordelt på uddannelserne medicin, farmaci og veterinær medicin.

Casens chattråde, som primært blev brugt af online-deltagende studerende under forelæsningen, er ligeledes brugt som reference til gruppeinterview samt som et blik ind på chat-kommunikationen.

Der gennemførtes to gruppeinterview (40 minutter) med 4-6 studerende for hver af de tre observerede forelæsninger; et med studerende, der havde været onsite-deltagende og et med online-deltagende.

Gruppeinterviewene med onsitestuderende blev afviklet umiddelbart efter forelæsningen, og umiddelbart derefter blev interviewene med onlinestuderende afviklet.

De studerende, der deltog i gruppeinterviewene, havde af egen vilje tilbudt sig som informanter. Der er således ikke tale om en kriterieudvælgelse. I alt deltog 15 studerende. Gruppeinterviewene blev gennemført ud fra en semistruktureret spørgeramme, hvor fokus var på, hvordan de studerende oplever HyFlex-organiserede forelæsninger og tilknyttet kommunikation (monolog/interaktion), henholdsvis onsite og online (muligheder og begrænsninger), kommunikationen 'på tværs' af de to undervisningsfora, samt hvordan de studerende deltager, fx stiller spørgsmål, melder sig til at svare på 
spørgsmål, bidrager med indlæg i diskussioner samt argumenter for hhv. deltagelse/ikke-deltagelse i kommunikationen. Yderligere blev de spurgt om, hvordan de støtter hinanden kommunikationsmæssigt (peerfeedback på opgaver, sociale platforme/fora i forbindelse med opgaver/aktiviteter osv.), og om hvordan de oplever studiekammeraters tilgang til det at være studerende i et HyFlex-organiseret undervisningsmiljø, samt om hvordan undervisningen kan tilrettelægges på den korte bane (foråret 2021) og på den lidt længere bane (efter corona-tid).

Der er inkluderet tre e-moderatorers oplevelser af de studerendes deltagelse onsite og online, chatkommunikationens mulige understøttelse af onlinestuderendes kommunikation under forelæsningen, e-moderators kommunikation som bindeled mellem onlinestuderende-forelæser og mellem onlinestuderende samt interaktionen mellem henholdsvis onsitestuderende og forelæser, og onlinestuderende og forelæser.

\section{Den empiriske undersøgelse}

Resultaterne af den kvantitative del af den empiriske undersøgelse vil først blive præsenteret. Derefter følger den kvantitative del.

\section{Den kvantitative del}

Tabel 1. Overblik over Casen.

\begin{tabular}{|l|l|l|l|l|l|l|}
\hline Studium & Kursus & $\begin{array}{l}\text { Onsite } \\
\text { stud. }\end{array}$ & $\begin{array}{l}\text { Online } \\
\text { stud. }\end{array}$ & $\begin{array}{l}\text { Stud. i } \\
\text { alt }\end{array}$ & $\begin{array}{l}\text { Stud. på } \\
\text { kurset }\end{array}$ & $\begin{array}{l}\text { Chat } \\
\text { posts* }\end{array}$ \\
\hline $\begin{array}{l}\text { BSc Farmaci, 3. } \\
\text { semester }\end{array}$ & Basal Farmakologi (2 timer) & 16 & 80 & 96 & 250 & 11 \\
\hline $\begin{array}{l}\text { BSc Medicin, 2. } \\
\text { semester }\end{array}$ & $\begin{array}{l}\text { Medicinsk psykologi og } \\
\text { sundhedspsykologi (2 timer) }\end{array}$ & 50 & 98 & 148 & 305 & 28 \\
\hline $\begin{array}{l}\text { BSc Veterinær- } \\
\text { medicin, 1. } \\
\text { Semester }\end{array}$ & $\begin{array}{l}\text { Cytologi og almen histologi (3 } \\
\text { timer) }\end{array}$ & 30 & 124 & 154 & 163 & 137 \\
\hline
\end{tabular}

${ }^{*}$ Her er kun medtaget chat posts om faglige emner.

Den kvantitative analyse bygger på data indrapporteret af e-moderatorerne og data fra de almindelige studieadministrative systemer. E-moderatererne tæller ved hver session antallet af tilstedeværende onsite og online efter ca. 15 min undervisning. Undervejs noterer de ned, hvor mange aktiverende tiltag underviseren inkluderer, især brug af quizzer, Padlet og antal gange i breakout rooms. Desuden noterer de data om lyd og billedkvalitet, og efter sessionen tæller de antallet af posts i chatten og hvor mange af dem, der handler om det faglige. Det hele skrives ind i en fælles database.

COBL har i alt registreret 282 sessioner (i alt 698 timer, ca $15 \%$ af samlet undervisningstimertal på fakultetet) i perioden 31/8-4/12 2020, der dækker alle sessioner, hvor e-moderatorer er blevet anvendt. Følgende tabel viser nogle centrale totaler fra registreringen som et billede af efterårets HyFlexaktiviteter: 
Tabel 2. Alle efterårets HyFlex-forelæsninger med COBL organiserede e-moderatorer

\begin{tabular}{|c|c|c|c|c|c|c|c|c|}
\hline & $\begin{array}{l}\text { Antal } \\
\text { ses- } \\
\text { sion- } \\
\text { er }\end{array}$ & $\begin{array}{l}\text { Timer } \\
\text { i alt }\end{array}$ & $\begin{array}{l}\text { Pro- } \\
\text { cent } \\
\text { online }\end{array}$ & $\begin{array}{l}\text { Onsite } \\
\text { stud. }\end{array}$ & $\begin{array}{l}\text { Online } \\
\text { stud. }\end{array}$ & $\begin{array}{l}\text { Total } \\
\text { stud. }\end{array}$ & $\begin{array}{l}\text { Gns. } \\
\text { chat } \\
\text { posts } \\
\text { / ses- } \\
\text { sion* }\end{array}$ & $\begin{array}{l}\text { Gns. } \\
\text { chat } \\
\text { posts/ } \\
\text { session } \\
\text { /online } \\
\text { stud* }\end{array}$ \\
\hline BSc Farmaci & 110 & 165 & $76 \%$ & 32 & 104 & 136 & 10 & 0,09 \\
\hline MSc Farmaci & 30 & 78 & $76 \%$ & 24 & 77 & 102 & 21 & 0,27 \\
\hline BSc Veterinærmedicin & 42 & 102 & $69 \%$ & 50 & 109 & 159 & 98 & 0,90 \\
\hline MSc Veterinærmedicin & 5 & 17 & $89 \%$ & 10 & 81 & 92 & 65 & 0,80 \\
\hline BSc Medicin & 12 & 30 & $68 \%$ & 42 & 90 & 131 & 28 & 0,31 \\
\hline MSc Medicin & 10 & 51 & $36 \%$ & 18 & 10 & 29 & 8 & 0,74 \\
\hline BSc Sundhed og Informatik & 8 & 29 & $30 \%$ & 24 & 10 & 34 & 6 & 0,62 \\
\hline $\begin{array}{l}\text { MSc Sundhed og } \\
\text { Informatik }\end{array}$ & 8 & 32 & $35 \%$ & 12 & 7 & 19 & 1 & 0,08 \\
\hline BSc Folkesundhed & 11 & 22 & $43 \%$ & 38 & 28 & 66 & 2 & 0,07 \\
\hline MSc Folkesundhed & 46 & 172 & $35 \%$ & 19 & 10 & 30 & 4 & 0,39 \\
\hline Total / gennemsnit & 282 & 698 & $71 \%$ & 32 & 77 & 109 & 25 & $\mathbf{0 , 3 3}$ \\
\hline
\end{tabular}

* Her er kun medtaget chat posts om faglige spørgsmål. Vores case hører til i de grå rækker.

Der er forskel på hvor mange studerende, der deltager i forelæsningerne, onsite eller online. På Farmaci var det 38\% (tabel 1, 38\%=96/250), på medicinkurset var det 49\%, mens 94\% af de tilmeldte var med til veterinærmedicinforelæsning.

I forelæsningerne, der indgår i casestudiet, er størstedelen af de 'fremmødte' studerende online, 89\% på farmaci, $66 \%$ på medicin og $81 \%$ på veterinærmedicin. I gennemsnit er der $74 \%$ online deltagende på alle de "store kurser" (medicin, farmaci, veterinærmedicin). Det skal sammenholdes med, at 50\% har lov til at komme til forelæsningen, så det er altså forholdsvis mange, som vælger at følge forelæsningen hjemmefra. Fordelingen er omvendt på de mindre kurser (Folkesundhed samt Sundhed og IT), som typisk har 40-80 studerende. Her deltager i gennemsnit kun $37 \%$ online. Artiklens fokus er på storholdsforelæsninger. I den kvalitative del tematiseres de studerendes refleksioner over kommunikationens mulighedsbetingelser på storholdsforelæsninger, og her italesætter de andre undervisningsformer, der kommer i spil, når undervisningen organiseres som holdundervisning.

Der er forskel på hvor mange, der skrev chatposts i de tre kursussessioner i Tabel 1. De veterinærstuderende skrev mest, mere end en post per onlinestuderende (1,1 posts/stud på 3 timer). For de medicinstuderende og farmacistuderende var tallene hhv. 0,29 og 0,14 posts/stud/session. Alle tre tal er tæt på gennemsnittene (tabel 2) for BSc Veterinærstuderende (o,9 posts/stud/session), BSc Medicinstuderende (0,31 posts/stud/session) og farmacistuderende (0.09 posts/stud/session). Da vores fokus er på kommunikationens mulighedsbetingelser, vil vi blot præsentere tallene og invitere til 
nye forskningsprojekter med hypoteser om fx betydningen af, om forelæsninger optages, at være 1.semester studerende, forelæsningsgenrer og chatanvendelser.

Brugen af studenteraktiverende software i casestudiet varierede. Medicinkurset havde 4 quizzer, en diskussion med sidemænd/breakout rooms og en afsluttende evalueringsøvelse, mens der i de to andre kurser var få IRE-triader og interaktionskæder. Det lave antal aktiviteter ligner meget det generelle billede fra alle HyFlex-forelæsninger. I 9\% af forelæsningerne blev der brugt Quizzer, i $3 \%$ Padlet og i 10 $\%$ af sessionerne blev der lavet breakout rooms. Breakout rooms fik tidligt et dårligt ry blandt forelæserne, da et fåtal af de studerende valgte at gå med i breakout rooms. I den kvalitative del af undersøgelsen bliver de studerendes tilgang præsenteret.

\section{Den kvalitative del}

Analysen bygger på studerendes erfaringer som deltagende i undervisningen (efteråret 2020, KU) og med HyFlex-organiseret forelæsning som den anvendte undervisningsform. Den kvalitative del består af observationer af HyFlex-undervisningen, lurking i chatforum, gruppeinterviews med studerende og E-moderatorers erfaringer, jf. afsnittet om det empiriske design.

Som nævnt indledningsvis har hver af de studerende mulighed for at deltage onsite hver anden forelæsningsgang, og de er så henvist til at deltage online hver anden gang, primært i Zoom-platformen. Forelæser befinder sig fysisk i auditoriet sammen med onsitestuderende og en e-moderator.

Forelæsningsobservationerne foregik online, da det ikke var muligt for forskeren at deltage onsite. Observationernes fokus var på kommunikation i henholdsvis onsite- og onlinefora/chatfora. Observationerne viste, at forelæsermonologer var fremherskende, men at der i varierende omfang indgik aktiviteter som svar på forelæser-initierede spørgsmål (I-R-E triader) og quizzer, som ligeledes kan karakteriseres som I-R-E-triader, men som kunne have udviklet sig til interaktionskæder, i fald forelæser fx havde opfordret onsitestuderende til at diskutere mulige svar med sidekammerat og onlinestuderende til at chatte om mulige svar før afstemningen. Generelt havde forelæsere primært deres kommunikative fokus på onsite-deltagerne, men via e-moderatorens markering, når der var spørgsmål fra online-deltagerne, besvarede forelæser disse spørgsmål.

De studerendes aktiviteter på chatten handlede primært om faglige spørgsmål til forelæser (I-R-Etriader), men også faglige spørgsmål til medstuderende og svar til medstuderende (forsker havde kun tilgang til chatkommunikation, der er 'til alle', ikke private chat i chatten). Der var en jævnt løbende faglig chataktivitet. E-moderatoren havde en central funktion både med at viderebringe de studerendes faglige spørgsmål til forelæser men også andre spørgsmål, som fx "Kan slet ikke følge med, kan hun prøve lidt langsommere, ville det være dejligt;)" hvorefter e-moderator skriver "Har allerede spurgt om hun kan gå igennem det langsommere". En studerende skriver derefter "Nogle, der fik skrevet det ned?" og e-moderator skriver derefter "men kan godt spørge igen", hvorefter en studerende skriver "fik kun halvdelen med" (Observation, chat 04.12.20). De studerende deler deres noter og deres viden i chatten, og e-moderator forsøger både at interagere med online-deltagerne og forelæser, onsite. Ud over faglige chat-temaer er der fortløbende gang i chattråde, der mere har karakter af fælles kommentering på diverse ikke faglige temaer.

\section{E-moderatorers generelle erfaringer med HyFlex-organiserede forelæsninger}

E-moderatorerne oplevede, at "størstedelen" (e2) af de studerende primært fulgte forelæsningerne online, og at onsite-deltagerne stillede færrest spørgsmål i plenum, men til gengæld brugte pauserne til at stille forelæser spørgsmål, hvilket er som før Coronatiden. "Det er sjældent, at en studerende i lokalet beder om at fă et svar uddybet, men online er der ikke de samme barrierer. Det er sandsynligvis fordi, 
de kan få lov at kommunikere til underviseren gennem en e-moderator" (e3). Denne tilgang til kommunikativ deltagelse blev også tematiseret af de studerende og giver anledning til at sætte fokus på kulturen og forventningsafstemning.

For at få en form for kommunikativ kontakt med online-deltagerne, bruger "nogle forelæsere at kikke direkte ind i kameraet og henvende sig direkte til den studerende"(e2). Når det drejer sig muligheden for at stille spørgsmål, har en af e-moderatorerne oplevet, at "mange undervisere er dygtige til at implementere Q/A session efter hvert emne, hvilket er rart, da jeg således har mulighed for at samle flere spørgsmål og stille dem"(e2). "De studerendes deltagelse, når de sidder med online, er meget forskellig. Det kommer i høj grad an på, hvilken årgang vi har med at gøre, hvilket fag, underviserne og tidspunktet for forelæsningen”(e3). (Casestudiet har ikke udfoldet disse vigtige parametre).

Der er flere perspektiver i spil, når det gælder online-deltagernes præmisser:

"Altså, der skal ikke gå lang tid fra spørgsmålet er stillet, til der kommer et svar. De kan godt føle sig "overset" eller at deres spørgsmål ender med at være irrelevante, hvis der går for lang tid mellem spørgsmål og svar. Det er noget jeg som udgangspunkt altid nævner over for underviseren. På den måde kan underviseren tage stilling til om det er noget han/hun ønsker at tage løbende, eller om det skal tages til sidst. Hvis underviseren foretrækker det tages til sidst, så skriver jeg det ud til de studerende med det samme [...]. Fordi studerende også har det med at dumpe ind, så sørger jeg for at sende dem en kvittering for deres spørgsmål og minde dem om at underviseren vil tage spørgsmål til slut". (e3)

Kommunikationen mellem e-moderator og henholdsvis forelæser og online-deltagerne opleves som vigtig. Det kan betragtes som en del af forventningsafstemningen for deltagelse i HyFlexforelæsningskonteksten. E-moderatorerne oplever alle, at

"chat-funktionen er guld værd for de studerende [...] Det kan være, at den studerende ikke fik en vigtig pointe med, og spørger sine medstuderende om andre fangede pointen. Det kan være, den studerende er i tvivl om noget og dermed gerne vil have et svar fra underviseren. Her er de også gode til at hjælpe hinanden eller tilslutte sig spørgsmålet." (e3)

En af e-moderatorerne har oplevet, at forelæsere bliver "sure" (e1) på de studerende, når de ikke møder frem. Ifølge e-moderator handler det om, at forelæser ikke er klar over, at der sidder mange studerende online og er seriøse. E-moderatorerne oplevede, at der var fuldt hus i auditoriet, selvom forelæsningen bliver optaget. E-moderator (e1) vurderer, at grunden til at de studerende ikke møder op, når de kan se forelæsningen som video, ofte er fordi de studerende ikke oplever, at de får noget ud af at møde op.

\section{Opsamling}

E-moderatorerne har været den kommunikative bro i bredeste forstand mellem online/onsite studerende og forelæser.

\section{Gruppeinterview med studerende}

Analysen af gruppeinterviewene er inddelt i seks tematikker, som er baseret på interviewsspørgsmålenes tematikker.

\section{Tema1: Fordele og ulemper ved onsite-deltagelse}

Flere studerende giver udtryk for at onsite-deltagelse betyder, at de bedre kan koncentrere sig. 
"[...]jeg er rigtig dårlig til at koncentrere mig, hvis jeg sidder bare derhjemme. Jeg er rigtig dårlig til at lytte efter i online. Når jeg sidder her fysisk tilstede, så føler jeg, at jeg bliver lidt inddraget ind i undervisningen". (Informant 2)

Disse onsitestuderende har yderligere fokus på, at der er få, der deltager onsite.

"Der er selvfølgelig væsentlig færre til stede i forelæsningssalene, hvilket godt kan virke underligt, men jeg tror også, at det kan føre til, at nogle studerende tør at melde sig mere på banen, fordi de skal tale over for færre mennesker". (Informant3)

Konteksten forskydes fra forelæsningskonteksten til en oplevelse af at deltage i mindre hold og dermed andre kommunikative forventninger og muligheder.

"det er blevet lidt rarere, der er få mennesker, det er ligesom klasseundervisningsagtigt. Så når underviser stiller et spørgsmål, så er man mere lidt nødt til måske at svare". (Informant1)

Ydermere fremfører studerende, at en fordel ved onsite-deltagelse er muligheden for at spørge sine medstuderende undervejs i forelæsningen og interaktion bl.a. initieret af forelæser.

\footnotetext{
"man kan sidde ved siden af sin sidemakker og det er lidt hurtigere at snakke med hinanden i forhold til breakout rooms, hvor man ikke kender hinanden, og der måske er en anden tone, måske er man mere tryg ved sige sine tanker højt ift. hvis det er nogen man ikke kender". (Informant5)
}

Det er et gennemgående tema for de studerende, at den kommunikative båndbredde har betydning for deres tilgang til de konkrete interaktionskontekster. En studerende tvister temaet og sætter fokus på forelæser: "fordelen er til forelæseren, så kan han få noget feedback ved at se på ansigterne [...]" (Informant7). Dette tema går igen i flere sammenhænge, hvor 'sorte skærme' (slukkede webcams) bliver tematiseret som en barriere for en fortløbende interaktion. (Der er ikke samlet data ind om omfang af sorte skærme).

Den sociale dimensions betydning pointeres af alle interviewede studerende. Som en studerende udtrykker det: "Jeg synes, det er godt at komme op [onsite] og snakke med nogen mennesker, være lidt social i stedet for bare at sidde derhjemme" (Informant 11). 'Arenaskift' har betydning for nogle studerende. "Det er en hel anden stemning man er i, når man træder ind på campus og koncentrationsniveauet er højere" (Informant 13).

De studerende fremfører at "ved mange forelæsninger er det meget gammeldags, og der kan jeg ikke se nogen fordel ved at være der, kontra at sidde derhjemme" (Informant6).

HyFlex-organiseringen betyder, at onlinestuderendes chatspørgsmål via e-moderator fremsættes med en vis forsinkelse under forelæsningen, hvilket opleves af onsitestuderende som forstyrrende i forhold til forelæsningsflow: "HyFlex, altså forelæsningen er sådan lidt afbrudt hele tiden, det med at emoderator skal gentage spørgsmål, det er ikke så flydende" (Informant9). En studerende fremfører, at onsite-deltagerne har mulighed for at få kommunikeret i pauserne, og det bliver ofte akualiseret.

\section{Opsamling, tema 1}

Ud fra et kommunikations- og systemperspektiv er der tale om to parallelt aktive sociale systemer, onsite-forelæsningen og online-chatten. Når e-moderator markerer onsite, at der er et online-chatspørgsmål skabes en 'kommunikativ bro' mellem online- og onsite-systemerne, hvilket nogle onsiteinformanter betegnede som forstyrrende, idet 'onsite-kommunikationsflowet', oftest forelæsers 
monolog, bliver afbrudt. Individuelle præferencer, hvad angår koncentration, sociale relationer og mulighed for interaktion har betydning for valg af undervisningskontekst, herunder forelæsers formåen.

\section{Tema 2: Fordele og ulemper ved online-deltagelse}

De studerende ser fordele ved online-undervisning som er af mere pragmatisk karakter, som geografisk afstand, sygdom, smitte og pauser.

"Positive ting med online er, at når der er pause, så holder jeg pause, jeg er god til at gå væk fra skærmen, og ud at vaske op eller ud på altanen og ta' noget luft, og få koblet fuldstændigt af og så sætte mig ved computeren, når det starter igen. Men forelæser skal have en pauseplan og overholde den". (Informant9)

En pointe, som fremføres af flere studerende, er, at forelæser skal forstå, hvilke præmisser onlinedeltagerne har. De har bl.a. behov for klar kommunikation om pauser og forventer, at tidsplaner overholdes.

Chat-kommunikationen giver onlinestuderende mulighed for at kommunikere i online-chat-konteksten både med hinanden og med e-moderator.

"folk er gode til at bruge chatten. Der er rigtig mange studerende, som aldrig deltager aktivt i forelæsningerne, så der er selvfølgelig mange, der ikke skriver i chatten, men ofte er der en god kommunikation mellem dem, der vælger at bruge chatten, hvor studerende kan svare, hvis der er et spørgsmål fra en anden studerende [...] E-moderator som et fint mellemled mellem chatten og forelæseren". (Informant3)

Chatten fungerer som et forum for kommunikative aktiviteter af både faglig og social karakter. "Chatten er blevet til, at vi spørger hinanden og svarer hinanden - sidemandsdialog" (Informant 14). "Chatten i Zoom fungerer rigtig godt, fordi man får uddybet mange ting, og man kan hjælpe hinanden, man kan spørge om noget, og så er der nogen andre, der kan svare inde på chatten”. (Informant8)

De online-deltagende studerende problematiserer udbyttet af selve forelæsningen.

"Jeg føler at det kan være svært at kapere det hele, når man er online, det at følge med i PP og hvor underviser peger og samtidig skrive noter, og underviser tegner på tavlen, det er svært, for jeg kan kun se en ting af gangen online, i onsite kan de se begge ting". (Informant14)

Det handler ikke kun om, at onsite-præmisserne er svære at overføre til online, men også om at "det er svært både at skulle følge med på skærmen, tage noter og følge med på chatten, når det er nyt stof" (Informant13), og at man som 1. års studerende oplever, at "det er svært at sidde derhjemme, når det er noget helt nyt" (Informant14). Netop ift. 1. års studerende, der, med den specielle studiestart i et coronaramt 2020-21, ikke har fået etableret sociale relationer, ikke har 'knækket koden' som universitetsstuderende, og ikke før har deltaget i bl.a. HyFlex-organiseret undervisning, ligger der en særlig vigtig opmærksomhed, som denne artikel ikke har mulighed for at udfolde, men blot pointerer vigtigheden af.

Et helt specifikt tema, som de studerende bringer op i interviewene, er brugen af breakout rooms.

"Jeg ved at størstedelen af mine studiekammerater hader breakout rooms, også mig selv. Det er virkelig surt at sidde hjemme og fă at vide, at nu er der bare tre mennesker som aldrig har snakket med hinanden før, og nu skal du i 4 minutter diskutere fagligt med dem. Det er svært at motivere sig selv til at gøre det. Når man er der, så sidder man 
sammen med dem man kender, så kan man lige sige, nåh, min kammerat skal vi lige ...

f2f er lettere". (Informant7)

De studerende er enige om at hvis breakout rooms skal bruges, så skal der tænkes i, at det skal være medstuderede, de kender, "det er bare tryghed" (Informant6), og resultatet er ofte "sorte skærme, - en lemmingeting: Så gider jeg heller ikke tænde for kameraet. Vil ikke gøre noget pinligt" (Informant7) og "man vil jo helst ikke komme til at lyde for dum i breakout rooms". (Informant5)

De studerende vil gerne diskutere faglige temaer, og de finder selv deres kommunikationsfora, som $\mathrm{fx}$ "Hvis jeg var hjemme, så sad jeg med mine veninder over Facetime eller et eller andet og snakker med dem, og så går vi tilbage til zoom." (Informant4)

Sammenhængen mellem det der skal være læringsudbyttet, det konkrete fag og forelæsningskontekst, tematiseres af flere studerende: "Er det bare udenadslære, hvor man bare skal kunne kaste det op til eksamen, synes jeg det er fuldstændigt ligegyldigt at kunne diskutere det med andre [...] "(Informant7). En pointe der inviterer til kritiske didaktiske refleksioner for den fremadrettede tilgang til undervisningsformer og -organisering, men også til dialog med studerende om, hvorfor faglig interaktion kan være frugtbar selv på de lavere taxonomiske niveauer (Mathiasen \& Andersen, 2020).

\section{Opsamling, tema 2}

De studerende tematiserer manglende lyst til at deltage i 'breakout rooms'-aktiviteter af forskellige grunde, hvilket er et væsentligt opmærksomhedspunkt, også set i et (akademisk) dannelsesperspektiv (Fossland et al., 2015). Samtidig fortæller studerende om nytten af chatkommunikation under forelæsningerne og om deres selvorganiserede alternative kommunikationsaktiviteter, hvilket sætter den sociale dimensions betydning og kommunikations mulighedsbetingelser i fokus, herunder de studerendes og undervisernes tilgange til deltagelse. Overordnet kan vi tale om vigtigheden af forventningsafstemning og italesættelse af kultur på hold-, uddannelses- og institutionsniveau.

\section{Tema 3: Kommunikation på tværs af onsite og online fora}

De studerende oplever ikke, at der er kommunikation mellem studerende på tværs af de to fora. Onsitedeltagende studerende åbner sjældent chatten, hvorimod online-deltagende studerende oftest har chatten åben. Deres 'livline' til forelæser. Enkelte studerende fortæller om kommunikation 'på tværs', når fx en online-deltager via Facebook kommunikerer med en onsite-medstuderende. Enkelte onsitedeltagende studerende fortæller, at de bruger chatten: "Jeg bruger chatten til at klippe ind i mine egne noter - hvis der er skrevet et forkert svar i chatten, så er der andre der går ind og siger nej, det er ikke rigtigt, det er det her der er det rigtige". (Informant8)

En speciel form for kommunikation 'på tværs' er i forbindelse med quizzer.

"Programmer som Shakespeak synes jeg er oplagt at bruge, da det er en let måde at få mange til at deltage. Derudover er det et fedt opbrud i en monolog, og det kan man gøre lige meget om man ser med hjemmefra eller fra campus". (Informant3)

Online-deltagende studerende oplever en vis inklusion, når forelæser inviterer til deltagelse i en quiz. "Quizzer plejede vi at bruge meget i undervisningen, og det fungerer meget godt, når man sidder derhjemme. Jeg føler stadig, jeg er med på campus” (Informant4)

De online-deltagende er enige om, at e-moderatoren har en afgørende funktion i forhold til kommuniktaionen.

"De forelæsninger, hvor der ikke er en E-moderator, kan man ikke kommunikere med forelæseren under forelæsningen. Nogle gange tjekker de da chatten i slutningen af 
forelæsningen og besvarer eventuelle spørgsmål til sidst, men de kigger ikke på den undervejs." (Informant3)

Som onlinestuderende har man ifølge de studerende en udfordring, når forelæser glemmer, at de ikke kan se, hvor han/hun peger på storskærmen, eller når forelæser bruger tavlen. Med e-moderatorens hjælp er disse udfordringer minimeret, da dynamisk kameraføring og billeder af tavler har givet onlinestuderende bedre muligheder for at følge med i forelæsningen.

\section{Opsamling, tema 3}

De studerende oplever, at der onsite ikke stilles så mange spørgsmål, som der stilles af de onlinedeltagende. Yderligere oplever de, at der blandt de online-deltagende er mange, der svarer i chatten på spørgsmål stillet både i chatten og af forelæser. Quizzer opleves af onsite og onlinestuderende som meningsfulde. Der er dog en udfordring for online studerende, som ikke har mulighed for hurtig 'sidemand(M/K)'-diskussion af stemmemulighederne, hvilket ud fra et kommunikationsperspektiv kan bidrage til læring og dermed videnskonstruktion (Mathiasen, 2015).

De studerende giver udtryk for, at HyFlex-organiseringen kan fungere, når der er tilknyttet en emoderator. De foretrækker denne form frem for 'rene' online-forelæsninger.

\section{Tema 4: De studerendes tilgang til deltagelse i HyFlex-organiserede forelæsninger}

De studerendes forventninger til forelæsninger fortæller om en tilgang til denne form for undervisning som primært en forelæsermonolog, dog afhængig af forelæser og dennes mulige inddragelse af $\mathrm{fx}$ quizzer, medstuderende-dialog i forbindelse med forelæsers spørgsmål og dennes invitation til svar (IR-E-triader) og plenumdiskussioner (interaktionskæder). "Langt det meste af tiden er det forelæseren, der fører en monolog, men det er forskelligt fra forelæser til forelæser. Nogle er gode til at stille spørgsmål ud i salen”. (Informant3)

Som den kvantitative undersøgelse også viser, benytter ikke alle studerende muligheden for at deltage som onsitestuderende hver anden gang

"Det med at dele op i to hold, det er lidt noget fis, man ikke behøver, fordi det er alligevel de samme få mennesker der dukker op". (Informant1)

Der er dog forskelle, hvilket de studerende tilskriver forelæsningskvaliteten i forhold til læringsudbytte. De fleste studerende oplever, at HyFlex har fungeret for dem, men flere pointerer, at de savner at kunne spørge forelæser og få opklaret et fagligt problem i pauserne. Samtidig ser de klare fordele ved, at der ikke er så mange i auditoriet, og nogle sammenligner denne situation med deres holdundervisning. "Selve princippet i HyFlex har været godt, vi sidder ikke 240 i auditoriet" (Informant4). Flere studerende tematiserer forelæsninger og læringsudbytte. "Forelæsninger fylder så meget i skemaet ift. hvad læringsudbyttet er. Det bliver mange tabt på"(Informant6). Udfordringen håndteres på forskellig vis." I min klasse er der nogle piger, der har 8 timers Facetime opkald, hvor de bare læser og vender ting, hvor jeg selv har en messengergruppe, hvor vi skriver alt muligt”. (Informant7)

Den kommunikative båndbredde og det kommunikative flow bliver bemærket af flere studerende: " [...] det med at man sidder der og kan være med til den der udveksling af info fra forelæseren og når man kan se, at de kan se reaktionerne fra os, det er helt klart noget." (Informant14). Det at forelæser og studerende kan få øjenkontakt bemærkes af flere studerende som en væsentlig forskel mellem onsiteog online-deltagelse. Forelæser vælger oftest en onsitestuderende til at svare på de stillede spørgsmål. 
"Det, at forelæser står foran folk i et auditorium, gør en forskel for os, der sidder derhjemme. Det kan godt være at man ikke er med i dialogen, men der foregår en dialog, og det gør bare en kæmpe forskel". (Informant14)

Onlinestuderende pointerer vigtigheden af deltagelse $\mathrm{i}$ en kontekst, hvor de kan iagttage onsitekommunikation.

\section{Opsamling, tema 4}

Når det handler om øjenkontakt, som de onlinestuderende er opmæsksomme på mangler, er et 'talking head'-webinar og en forelæsningsvideo i auditoriet med deltagende onsitestuderende i samme kategori (Mathiasen, 2019a). Men det, at onsitestuderende sidder i auditoriet, giver onlinestuderende en mulighed for iattagelse af kommunikationen og auditoriesituationen, som kan opleves som bidragende til motivationen.

De studerende pointerer det problematiske i forholdet mellem antallet af forelæsinger og deres oplevede læringsudbytte. Nogle studerende er specielt udfordret, hvilket inviterer til fortsat forskning med fokus på onsite/online- forelæsningsformater og deltagelsesfravalg/frafald.

\section{Tema 5: De studerendes egenvurdering af læringsudbyttet ved deltagelse i HyFlex-organiserede forelæsninger}

De studerende har forskellige præferencer og erfaringer i forhold til HyFlex-organiserede forelæsninger og eget læringsudbytte, men de er enige om, at "det er en stor hjælp, at man kan gense forelæsningerne"(Informant3) og det særligt med henblik på eksamenslæsning.

Nogle af de studerende "kan godt lide at bare lave selvstudie, og det er der mange af mine medstuderende der også kan, - læse en bog, og så ved siden af have nogle forelæsninger, der giver mig viden på en anden måde" (Informant7). Her har den studerende en pointe, idet bogens faglige formidling er kommunikeret på en måde (skriftlig), mens videoforelæsningerne tilbyder den faglige formidling på en måske mere udfoldet måde, hvis forelæser (mundtligt) formidler det faglige stof og samtidig understøtter denne formidling med slideshow, animationer, lyd mm (Mathiasen, 2008).

En studerende formulerer sin oplevelse på denne måde:

"Jeg forstår det nogle gange bedre, når jeg får italesat det, laver nogle opgaver sammen og sparring med læreren. I forelæsningerne er det hip som hap om jeg sidder hjemme eller var der, men holdundervisning er noget andet". (Informant6)

Kommunikation med forelæser og medstuderende er vigtig, og interaktion i forelæsningsformatet opleves som fraværende, og derfor er det 'hip som hap'. "Man mister bare alt det sociale og det har vi gjort et halvt år nu, altså jeg er bare en tom skal af et menneske, der kan spytte viden ud". (Informant7)

De studerende påpeger en dalende motivation og savn af sociale aktiviteter, så de kan sparre med hinanden og spejle sig i hinanden.

\section{Opsamling, tema 5}

Studerende har forskellige præferencer, men er generelt enige om, at holdundervisning ikke skal afvikles som HyFlex, men som onsite-undervisning og at de har savnet den sociale dimension og relaterede aktiviteter, hvilket handler om muligheden for kommunikation i onsitekontekster, hvor de kommunikative virkemidler er flere og dermed kan sandsynligheden for interaktionskæder øges (Mathiasen, 2021). 


\title{
Tema 6: Gode råd fra de studerende, på kort sigt og på lidt længere sigt
}

De studerende foreslår klar kommunikation fra forelæserne om praktiske forhold. Yderligere er et forslag, at "Underviserne skal bruge Absalon (KU's LMS, red.) til info mellem forelæsningerne. Mere kommunikation mellem forelæser og studerende, $\mathrm{fx}$ at en forelæser stillede et spørgsmål til de studerende efter hvert slide." (Informant4)

Ønsket om mere information og interaktion er gennemgående, det samme gælder ønsket om, at alle forelæsninger bliver optaget. De studerende pointerer, at online-deltagerne ikke må blive overset.

\begin{abstract}
"Overvej at holde fast i optagede forelæsninger. Det er et konservativt koncept på en eller anden måde. Der er nogen der får meget ud af det og der er nogen der ikke făr en hylende fis ud af det. Men den generelle stemning er, at det er godt, at vi kan se dem optaget. Det kan man godt holde fast $\mathrm{i}$, når corona er ovre, men holdundervisning og laboratorieundervisning kan man ikke kompensere for online, kun forelæsninger." (Informant6)
\end{abstract}

De studerende er enige om, at HyFlex-organiseret undervisning kun egner sig til forelæsningsformatet. "Lad være med at tage vores holdundervisning fra os. Der står en og snakker og det er ikke interaktion" (Informant7).

Udfordringen på det sociale fylder en del hos de studerende, både det at "de gerne vil have følelsen af at gå på universitetet og at lære folk at kende og stedet at kende". (Informant13)

Selvom de fleste studerende ikke ønsker at deltage i breakout rooms, hvor de ikke kender de andre, så har nogle studerende haft en god oplevelse med disse. De fik lavet "opgaven, fik spurgt om hvordan har du det med det, synes du også det her er svært, bruger du også 100 år på at læse det, hvad synes du om forelæser? Altså bare de der små ting” (Informant15). Den studerende peger i interviewene på, at der udover det faglige også er muligheder for at spejle sig og sparre i disse rum, og at det kan have en positiv effekt på motivation og lyst til at fortsætte som studerende. Muligheden for at opretholde de etablerede sociale systemer og dermed den fortsatte kommunikation tillægges stor betydning.

\section{Opsamling, tema 6}

Omdrejningspunktet er igen kommunikation og dennes mulighedsbetingelser (hold/storhold). Underviserne opfordres til at forstå vigtigheden af klar rammesætning for forelæsningerne.

De studerende har forskellige tilgange til deltagelse i bl.a. breakout rooms. De, der har reflekteret over nytten ved at deltage aktivt, har set disse kommunikative rum som et sted, hvor de satte sig selv i spil og fik mulighed for at diskutere, spørge, få en fornemmelse af egen faglige 'position' og bringe sig selv i spil i forhold til opbyggelse af sociale relationer.

\section{Konklusion}

Vi har i den kvalitative del af undersøgelsen spurgt om, hvordan betingelserne for kommunikation i HyFlex-undervisningsorganisering opleves af de studerende, og hvilke tilgange og præferencer, de i den sammenhæng giver udtryk for. I den kvantitative del har vi undersøgt volumen af de studerendes kommunikative deltagelse i HyFlex-organiseret undervisning med tilknyttet e-moderator. Det anvendte kommmunikationsbegreb har vi valgt, fordi det gør det muligt at stille skarpt på studerendes og underviseres muligheder for forskellige typer af interaktion. Når de studerende er enige om, at HyFlex er et godt og fleksibelt forelæsningsformat, er deres argumenter, ud over de mere pragmatiske fleksibilitetsrelaterede argumenter, at onlineundervisning oftest gennemføres som forelæserformidlet information til de studerende. Denne envejskommunikation, der i overvejende grad er aktualiseret, når 
konteksten er 100+ studerende i et auditorium, er udfra det anvendte kommunikationsbegreb en måde at håndtere kompleksiteten i det sociale system. Interaktion i form af mere end IRE-kæder har vanskelige vilkår, da konteksten ikke inviterer til plenumdiskussioner. Og selv IRE-kæder kan være vanskelige at få til at fungere af rent praktiske/fysiske grunde. Men også fordi studerende er opmærksomme på, at deltagelse med kommunikative bidrag i auditoriet kan medføre, at medstuderende danner sig en forståelse af den ytrede information, som kan resultere i en 'stempling' som ikke formående. De studerende pointerer den sociale dimensions afgørende betydning for deres tilgang til det at være studerende. En udfordring i denne sammenhæng er at etablere en kultur, der omfavner det at fejle og 'dumme sig'. Den sociale dimension bliver så at sige fattigere på kommunikativt indhold, hvis de studerende er for selvcensurerende. I et dannelsesperspektiv er det en pointe, at de studererende kan og vil indgå i diskussioner, også når det handler om auditorieformatet.

De studerende ønsker muligheden for at have onsite-interaktion med underviser og medstuderende, men når undervisningsformatet er storholdsforelæsninger, vælger mange $(74 \%)$ at se forelæsninger hjemmefra.

Når de studerende pointerer, at holdundervisning (ca. 30 personer) og laboratorieundervisning ikke skal være HyFlex-organiseret undervisning, handler det igen om kommunikationens mulighedsbetingelser. De studerende oplever, at interaktion med underviser og mellem studerende har betydning for såvel den faglige som den sociale udvikling. Den sociale dimension pointeres som værende et afgørende opmærksomhedspunkt i rammesætningen af undervisningsmiljøerne. E-moderatorfunktionen er det vigtige bindeled mellem onsite og online undervisningsmiljøerne. Det handler om kommunikationens mulighedsbetingelser og facilitering af kommunikationen.

De studerende fremhæver svagheden ved webinarformatet, hvor forelæser optræder som 'talking head'/slideshow. Der er ikke mulighed for udfoldet kommunikation, hverken IRE-triader eller interaktionskæder, hvilket ikke opleves som motivativerende. HyFlex-organiserede forelæsninger, hvor e-moderator er kamerafører, oplever onlinestuderende som et mere motiverende og engagerende undervisningsmiljø. Når forelæser bruger kropssprog, skriver på tavle, peger på storskærm, spørger studerende i auditoriet og får svar fra onsitestuderende samt at e-moderator stiller forelæser spørgsmål fra chatten, og forelæser svarer, oplever de studerende en kommunikativ udfoldelse af deres muligheder for at tilslutte sig kommunikationen. Flerheden af kommunikative virkemidler pointeres som vigtig for forståelsen af den ytrede information.

De studerende kommunikerer med hinanden under forelæsningen i chatten, og de bidrager både med spørgsmål og svar. Det er primært studerende, der følger forelæsningen online, der bruger chatten, men også onsitestuderende bruger chatsvar og klipper dem ind i deres noter. Onlinestuderende giver udtryk for, at der spørges mere på chatten end i auditoriet. Begrundelserne handler primært om ikke at ville "dumme sig", "udstille sin uvidenhed" eller "stikke ud", når man sidder i auditoriet, men også i breakout rooms kan denne tilgang observeres. Her kunne en dannelsesdiskussion være aktuel, og et spørgsmål om hvad universitetsundervisning set i et dannelsesperspektiv skal tilbyde.

Et opmærksomhedspunkt, som inviterer til didaktiske refleksioner, er, at de studerende deltager i chatkommunikation, men ikke i samme grad i den mundtlige synkrone kommunikation. Casestudiet viser ikke, at denne tilgang til kommunikativ deltagelse er specifikt knyttet til et kursus, et studie eller en årgang.

For nogle studerende med præference for onsite deltagelse handler det om at "se og snakke" med andre studerende onsite, skabe kontakt, sparre med sine medstuderende og spejle sig i dem. For andre er det at kunne deltage onsite en mulighed for at fastholde koncentrationen og fokus på kommunikationen. Uanset præferencer er fundamentet for deltagelse kommunikation. Derfor er det vigtigt, at der til stadighed er fokus på kommunikationens mulighedsbetingelser i de rammesatte undervisningsmiljøer. 
Casestudiet viser, at de studerende tillægger muligheden for at tilgå forelæsningsvideoerne efter behov betydning og specielt til eksamensforberedelse, fordi de på dette tidspunkt er et andet sted fagligt end dengang, de så forelæsningen første gang. Dermed kan denne 'envejskommunikationslæringsressource' bygge på den aktuelle viden og medvirke til en dybere forståelse. Med den anlagte teoretiske ramme kan forelæsningsvideoer som nævnt betegnes som et fagligt formidlingsformat, hvor sekvenser af en kommunikationsenhed processeres.

Blandt de studerende er der opbakning til at fortsætte med HyFlex-organiserede forelæsninger, der livestreames fra auditoriet med en tilknyttet e-moderator, og som er tilgængelig som videoressource bagefter. Der skal være mulighed for onsite-deltagelse ('auditoriestemningen'). De onlinestuderende pointerer, at det at kunne følge IRE-triader/interaktionsmønstre er motiverende. Kommunikationen folder sig forskelligt ud i forskellige fora og i forskellige fysiske kontekster, hvilket er konditionerne for sociale systemer. Uforudsigeligheden er på sin vis det, som de studerende også pointerer som motiverende og engagerende.

\section{Referencer}

Beatty, B. J. (2019). Hybrid-Flexible Course Design. EdTech Books.

Braun, Virginia, and Victoria Clarke. 2006. Using Thematic Analysis in Psychology. Qualitative Research in Psychology 3(2):77-101.

Creswell, J. W \& Clark, V. L. P. (2017). Designing and Conducting Mixed Methods Research. SAGE Publications

Flyvbjerg, Bent. 2010. Fem Misforståelser Om Casestudiet. Pp. 463-87. Kvalitative metoder. Hans Reitzels Forlag.

Fossland, T., Mathiasen, H., \& Solberg, M (Eds.) (2015). Academic Bildung in Net-based Higher Education. New York \& London: Routledge

Georgsen, M., \& A. Qvortrup. (red.) (2021). Erfaringer og oplevelser med online undervisning på 9 videregående uddannelsesinstitutioner i foråret 2020. Tilgået online d. 11.02.2021

https://www.ucn.dk/Files/Billeder/ucn/Forskning/COVID\%2019\%20undervisning\%20samlet\%20rapport.pdf

Hammersley, M. \& Atkinson, P. (1987). Feltmetodik. Grundlaget for feltarbeid og feltforskning. Oslo: Gyldendal Norsk Forlag

Jensen, L. X., Karstad, O. M., Mosbech, A., Vermund, M. C., \& Konradsen, F. (2020). Experiences and challenges of students during the 2020 campus lockdown. Results from student surveys at the University of Copenhagen (pp. 1-73, Rep.). Copenhagen: University of Copenhagen. Tilgået online d. 08.02.2021 https://cobl.ku.dk/2020lockdown

Kragelund, L., Moser, A. \& Zadelhoff, E. van (2015). Using the Obser-views in Qualitative Research: Benefits and Challenges. International Journal of Qualitative Methods, 1/9.

Kvale, Steinar. 1997. Interview - En Introduktion Til Kvalitative Forskningsinterview. 1. udgave. Hans Reitzels Forlag.

Lemke, J. L. (1990). Talking science: Language, learning and values. Norwood, New Jersey: Ablex Publishing Corporation

Luhmann, N. (1988). Erkenntnis als konstruktion. Berlin: Benteli Verlag

Luhmann, N. (1992). What is Communication? Forum, Communication Theory, 2/3, s. 251-258

Luhmann, N. (1995). Social systems, Stanford: Stanford University Press

Mathiasen, H. (2006). A Consecutive Research Design Inspired by Systems Theory. Mixed Methods Research, San Francisco: AERA,

Mathiasen, H. (2008). Is There a Nexus between Learning and Teaching? Communication as a Facilitator of Students' Knowledge Construction. I C. Holtham, \& C. Nygaard (ed.), Understanding Learning-Centred Higher Education. Frederiksberg: Copenhagen Business School Press

Mathiasen, H. (2015). Digital Voting Systems and Communication in Classroom Lectures - an empirical study based around physics teaching at bachelor level at two Danish universities. Journal of interactive media in education. https://jime.open.ac.uk/articles/10.5334/jime.ah/

Mathiasen, H. (2019a). Video, en læringsressource i universitetsundervisningen. Tidsskriftet Læring Og Medier. 12(21)

Mathiasen, H. (2019b). Flerholdsforelæsninger på gymnasiet - hvorfor det? Kognition \& Pædagogik, 29/ 114

Mathiasen, H., van Baalen, P., Keustermans, L. \& Haarhuis, J. (2020). Digital Transformation of LERU Universities during Corona Crisis Times. LERU 
Mathiasen, H. \& Andersen, L. A. (2020). Development of Critical Thinking in Higher Education: A Didactic Approach to the Challenge of Developing Student's Critical Thinking skills. European Journal of Education. http://www.eu-journal.org/index.php/JEE/article/view/242/248

Mathiasen, H. (2021). Campus- og netmedierede undervisningsformer: - et kommunikationsperspektiv. Tidskriftet KvaN, 41/119

Mehan, H. (1979). Learning lessons: Social organization in classroom. Cambridge, MA: Harvard University Press

Scott, P. H., Mortimer, E. F. \& Aguiar, O. G. (2006). The Tension Between Authoritative and Dialogic Discourse: A Fundamental Characteristic of meaning Making Interactions. High School Science Lessons. Wiley InterScience.

Wubbels, T. \& Breckelmans M. (2005). Two decades of research on teacher-student relationships in class. International Journal of Educational Research, 43, 6-24

\section{Links}

www.postpandemicuniversity.net tilgået online d.15.02.2021

https://uniavisen.dk/to-forelaeseres-gyserdagbog-fra-en-maaned-med-digital-undervisning/tilgået d. $\underline{12.02 .2021}$

https://www.uu.nl/sites/default/files/LERU\%20Dig\%20Trans\%20Summery\%20to\%20LERU\%20website.pdf tilgået d. 16.02.2021 


\section{Forfattere}

\section{Helle Mathiasen}

Professor

Københavns Universitet

Forskningsfelt siden 8o’erne: Pædagogik, didaktik og teknologianvendelser, - set i et lærings- og kommunikationsperspektiv

\section{Henrik Bregnhøj}

E-læringskonsulent

Københavns Universitet

Har arbejdet med e-læring som underviser og konsulent på DTU, KU og i konsultvirksomheder siden 2004 